\title{
DEVELOPING A CHILD'S AUTHENTIC LEARNING EXPERIENCE THROUGH MEDIA: TEACHERS' APPROACH
}

\author{
Rasa Braslauskienè \\ Klaipèda University, Lithuania \\ Reda Jacynè \\ Klaipèda University, Lithuania \\ Rosita Vaičiulè \\ Klaipėda University, Lithuania
}

\begin{abstract}
The article analyses the development of an authentic experience for primary school students as a result of experiential learning. Possibilities of developing children's authentic experience through media are discussed, as the ability to find, perceive and critically assess and use information and media content, as well as to express oneself, are one of the most important human abilities in the $21^{\text {st }}$ century. The article presents a qualitative research of the attitudes of primary education teachers about the development of a child's authentic experience by using media. The following research revealed that the method of accumulating authentic experience has a positive effect on students' learning motivation, allows to develop critical, creative thinking, constructs a real connection with teaching materials and practice, enables students to operate actively, independently, and be responsible for their own learning. The research highlighted the advantages and disadvantages of developing an authentic learning experience through media.
\end{abstract}

Keywords: authentic learning experience, experiential education, media.

\section{Introduction}

The need for learners of creating authentic experiences and experiential education is determined by the constantly changing education system, development of information technologies, which form different human educational needs, encourage to discuss the qualitatively new educational process. In order to fully assess the place of experiential education in the Lithuanian legal and educational system, it is necessary to indicate the strategic documents of Lithuania, which determine the direction and guidelines of education. The most important strategic documents in the area of education are:

- Lithuania’s Progress Strategy “Lithuania 2030”; 
- National Education Strategy 2013-2022 (prepared by taking into account the provisions of the Lithuania's Progress Strategy "Lithuania 2030").

The change of educational paradigms and new emerging trends in the change of educational content allow to reveal the importance of a child-centred paradigm. The following paradigm focuses on the child and emphasizes that one's uniqueness, needs, regularity of development determine the individual approach to a child and one's environment. Today, there is a global recognition of the need to look for new learning/teaching opportunities, whereas the traditional teaching model should be used less often (Global Challenge Insight Report, 2016). Experiential education, including the construction of authentic experiences, today is defined as philosophy and methodology, when teachers consciously use the direct experience of learners to expand knowledge and develop skills (Braslauskienè, Norvilienè, Šmitienè, 2018).

Since the European Parliament legitimized the topic of media training in education in 2009, endorsing its inclusion in curricula at all levels of education, it became important to develop children's authentic experience by using and exploiting the full potential of the digital age (Grizzle, 2011). In order to properly master the possibilities of media education, not only do educators need to get acquainted with and evaluate information communication technology tools, be able to apply them, properly organize parental education, etc., but also use real world objects to help children develop authentic learning experience by creating real learning opportunities and simulating real-life experiences, etc.

The aim of the following research is to find out the opinion of primary education teachers about the development of a child's authentic experience through media.

Methods: analysis of scientific literature, interviews, content data analysis.

\section{Theoretical Assumptions of Experiential Education and Acquisition of Authentic Learning Experience through Media}

G.Voukelatou (2019) claims that rapid social and cultural development influences the increase of educational needs and the emergence of new teaching/learning methods in the educational process. S.Vosniadou (2011) described the important results of recent research on learning that is relevant for education. The attempt to integrate research comes from diverse areas of psychology, including educational, developmental, cognitive, social and clinical psychology. The following research has offered us new insights into the learning process and the development of knowledge in many subject-matter areas. As a result, curricula and instruction are changing in schools today. They are 
attempting to become more student-centred than teacher-centred, to connect the school to real-life situations. Authentic learning is defined as learning that is seamlessly integrated or implanted into meaningful, "real-life" situations (Jonassen, Howland, et al., 2008). Also, it is stated that in authentic learning, learners are presented with realistic problems or projects that have realistic purposes and given the opportunity to investigate and converse about these problems and projects in manners that are applicable to them and their lives (Carlson, 2002; Mims, 2003; Iucua, Marina, 2014).

As claimed by the philosopher J.Dewey (cit. from Braslauskiene, Norvilienè, Šmitiene, 2018), who developed the theory of pragmatic constructivism, study subjects should not be learned separately, education should start from the child and his / her authentic experience, it should be contextual. According to J. Warren, K. Hof, L. Morris et al. (2012), students learn more and assimilate learning materials more easily when the teaching/learning is based on real and specific life events and existing students' experiences.

Creating an authentic human experience and ideas of experiential education have been known from the earliest time of humans and human education. From learning being passed though storytelling and oral tradition to Plato's dialogues about the human soul, and continuing education, experiential education has prevailed as a dominant mode of learning in Western culture (Breunig, 2005). The importance of the student's experience is especially evident in the application of experiential education. It is a strategy of active student-centred learning that is based on the ideas of constructivist theory. Such education pays a lot of attention to learning environments, personal needs and motives. The following learning theory draws attention to the process when learners actively construct and make their own and authentic knowledge. During the process, new ideas, concepts, and meanings are created on the basis of previously acquired knowledge and experience (Monkevičienè, Sakadolskis, Bruzgelevičienè et al., 2014).

According to O.Vaščenkienè (2012), the essence of modern education can be summarized as follows: it is important to focus on the development of student's personality, on one's own active and conscious learning, by providing the student with appropriate support to develop life-critical competencies. Modern teaching/learning should comply with the following principles: it should be realistic, relevant, attractive, motivating; it should be clear, precise, i.e. aimed at a specific goal and addressee; it should give students autonomy; it should be adapted for students with different teaching/learning needs and styles; it should create opportunities to take on different roles and responsibilities; it should broaden horizons and encourage to seek more. G.French (2007) points out that every learner can and should become a source of learning, as everyone's experience is individual, and therefore, unique and authentic. In this way, new 
awareness is constructed, new knowledge is created here and now, learning/teaching process becomes very dynamic (Monkevičienè, Sakadolskis, Bruzgelevičienè et al., 2014).

G.Petty (2006) argues that authentic learning occurs when individuals act freely and strive to foster each other's growth and development. An authentic personality is a free personality; thus, the student's autonomy is important in fostering authenticity. C.Mims (2003) claims that authentic learning provides an opportunity for students to explore, discuss and construct concepts and relationships in contexts that encompass real-world problems. If learning is authentic, then students need to explore real educational issues that allow for direct connections between new material and prior knowledge. Authentic teaching/learning, which encourages to reflect on and analyse one's own experience and to learn from it, at the same time urges to get to know oneself better as a person and a learner. Moreover, it provides teachers and other learners with a lot of useful information about the learner. In other words, authentic teaching/learning permits to get to know not only the surrounding world, but also oneself. Therefore, teaching can be adapted to the individual abilities and needs of the learner (Moon, 2005).

Authentic assessment is a powerful tool for educators to analyse information gathered during everyday classroom activities and routines in order to understand each unique child's development. Consistent and comprehensive reflection on observation notes, photos, artistic creations, emergent writing, and dictations provides teachers with meaningful insight about each child and about the group as a whole. With this insight, teachers can plan activities and experiences that are responsive to children's interests and needs. Teachers can share their understanding of each child's growth with his or her family, while also gaining important insight from them in return (Anderson, Hartwig, 2016).

R. Gaučaitè, A. Kazlauskienè, E. Masiliauskienè et al. (2012) state that the essence of an authentic learning strategy is that a personality develops through personal experience. The increased freedom of the learner not only allows to actively construct one's process of learning, but also enables one to take greater responsibility for learning outcomes, strengthen motivation and become more involved in the teaching/learning process. The following learning process includes innovative learning methods, rather than traditional ones.

Digital technologies have revolutionised our society, and children today grow up and live in a world where these are ubiquitous. The $4^{\text {th }}$ industrial revolution, the term originally coined by K. Schwab (2016) to describe the spread of digital technologies, affects all aspects of life, from health to commerce, from social interactions to the way people work. Education systems are no less affected, not only because technology can impact the way education is delivered, but also 
because education has a role to play in preparing young people for a tech-driven world.

R. Jančiauskaitè (2016) claims that the ability to find, perceive and critically assess and use information and media content, in this way also expressing oneself, is one of the most important human skills of the $21^{\text {st }}$ century. Information reaches us both in digital format and when visiting libraries, archives, museums, we can receive it from other people, organizations. Information flows are very high and we must to be able to effectively find, obtain, assess, select and use it ethically and responsibly.

According to B. Šupšáková (2016), media education creates a space for young people to freely express themselves and exercise their right to obtain information. It is beneficial for their personal development, and it enhances their participation and interaction in society, thus preparing them for democratic citizenship and political consciousness. The media education curriculum must socialize young people, to acquire experiences from social changes (Buckingham, 2000).

Media education is being developed to help children cultivate their curiosity, learn how to evaluate the highest variety of questions and situations in various contexts and at differing complexity levels, accept diverse perspectives, and optimistically consider the future. As reflected in the educational practice, media education at the primary level of education should include all personal levels of children/students as well as children's cognitive (basic orientation in the media environment, recognition of differences and diversity, decoding of the 'reality' represented by the media, understanding of the positive and negative impacts of the media, etc.), psychomotor (active communication in the media environment, creation of their own media content, ability to collaborate and communicate with the media environment), and attitudinal (ability to develop their own attitudes towards media products, ability to critically analyse, responsibility for content creation, etc.) functions (Šupšáková, 2016).

Summarizing the theoretical assumptions of experiential learning and acquisition of authentic learning experience by applying media, it can be stated that the axis of experiential education is the experience available and constantly acquired by students. The strategy of authentic teaching/learning experience applied by teachers allows students to become more active participants of the teaching/learning process, giving meaning to the already existing and acquired experience. 


\section{Methodology of Research}

According to V. Žydžiūnaitè, S. Sabaliauskas (2017) qualitative research helps to understand and interpret the social world, while human behaviour is perceived as being dynamic, situational, helping to investigate cases without aiming at representativeness.

Participants of the research. The sample of informants when performing qualitative research depends on the aim of the research (Bitinas, 2013). Since the research sought to reveal the opinion of primary education teachers about the development of the child's authentic experience through media, sample units selected for the qualitative research from the general sets were chosen by applying the targeted sampling method. Targeted sampling is such sampling, when the researcher selects elements for the sample depending on the aims of the research.

The targeted selection allowed to choose individuals who can provide the researcher with meaningful information on the subject. In this case, it is primary education teachers who apply media for the development of a child's authentic experience. The participants of the research were 15 teachers of 1-4 grades of general education schools of Klaipeda city, aged 25 to 51 . Such sample is sufficient, because when applying the semi-structured interview, the recommended sample size is from 5 to 30 people (Žydžiūnaitè, Sabaliauskas, 2017). It was established that 6 of the respondents have up to 5 years of pedagogical work experience; 7 teachers have more than 15 years of work experience, but not more than 25 years; and 2 indicated that their pedagogical work experience is more than 25 years, but not more than 30 years.

The research was conducted in September - November 2020. The semistructured interview method was chosen for the implementation of the research being one of the most convenient survey methods during which it is possible to obtain as much unstructured information about the research issue as possible. Semi-structured interview provides the researcher with an opportunity, depending on the course of the interview, to steer the questions in the right direction. The obtained interview data were analysed by the method of content analysis: on the basis of the theoretical analysis the categories of the researched phenomenon were identified and the obtained data were assigned to them, the obtained results were interpreted and analysed, examples and category illustrations have been provided. This is a valid method that allows conclusions to be drawn on the basis of the analysed text (Bitinas, 2013). The following ethical principles have been followed during the implementation of the qualitative research (interview): goodwill, respect for the dignity of a person, justice, right to obtain accurate information. 


\section{Research Results}

The qualitative research of opinions primarily sought to find out the opinion of informants about why do you use the method of accumulating children's authentic learning experience in children's education? The obtained data are presented in Table 1.

Table 1 Use of the Method of Accumulating Children's Authentic Learning Experience in Education

\begin{tabular}{|c|c|c|c|}
\hline Category & Subcategory & Statements & $\begin{array}{l}\text { Number } \\
\text { of } \\
\text { responses }\end{array}$ \\
\hline \multirow[t]{2}{*}{$\begin{array}{l}\text { Method of } \\
\text { accumulating } \\
\text { authentic } \\
\text { learning } \\
\text { experience in } \\
\text { education }\end{array}$} & $\begin{array}{l}\text { Learning } \\
\text { motivation }\end{array}$ & $\begin{array}{l}\text { "Hard learners can enjoy success, while good } \\
\text { learners have an excuse to compete" } \\
\text { "Encourages students to get to know } \\
\text { themselves better and to understand their role } \\
\text { in the educational process" } \\
\text { "Encourages students to understand their } \\
\text { potential, experience success" } \\
\text { "Students deepen their knowledge in an area } \\
\text { that interests them" } \\
\text { "Have an opportunity to learn what they want" } \\
\text { "Compete to read more pages of a particular } \\
\text { book, report by describing them" } \\
\text { "The content of lessons is aligned with students } \\
\text { so that they can learn what they want" } \\
\text { "Helps students stay motivated to learn" } \\
\text { "Provides opportunities to be autonomous, } \\
\text { active, independent and responsible for one's } \\
\text { own learning" } \\
\text { "Can rejoice in their success, there is an } \\
\text { opportunity to compete for better results" } \\
\text { "Students can share their knowledge" } \\
\text { "Encourages children to work in a team" } \\
\text { "Encourages, motivates weaker students to get } \\
\text { involved, to rejoice in the success of the team" } \\
\text { "Hard learners experience the joy of learning, } \\
\text { feel great in the classroom" }\end{array}$ & 14 \\
\hline & $\begin{array}{l}\text { Development } \\
\text { of critical } \\
\text { thinking }\end{array}$ & $\begin{array}{l}\text { "Promotes critical thinking skills" } \\
\text { "Creates learning conditions that provide an } \\
\text { opportunity to organize, interpret, explain, } \\
\text { evaluate, research, analyse" } \\
\text { "Students accumulate information using } \\
\text { various methods" }\end{array}$ & 15 \\
\hline
\end{tabular}




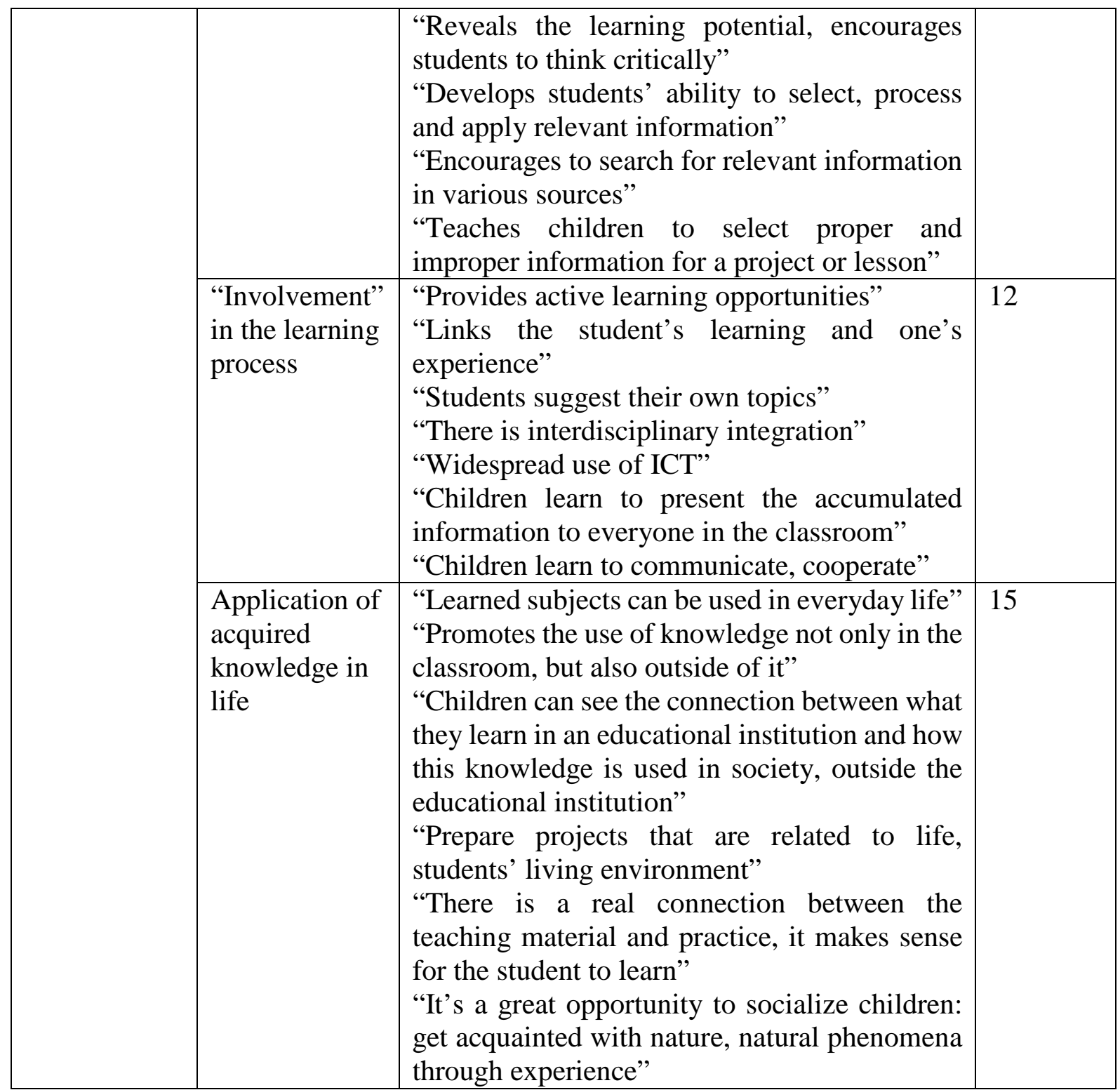

According to educators, the method of accumulating authentic experience in children's education has a positive effect on learning motivation, makes the teaching process inclusive, and "education is most suitable for all students in terms of life readiness" (European Agency for Special Needs and Inclusive Education, 2014, p. 7). The increase of learning motivation is related to children's needs, goals, values and habits, helps students to focus on the goal and understand how long it will take to achieve the goal, whether and what kind of reinforcement is needed, actualizes the necessary knowledge, abilities and skills of students, has an impact on the quality and outcomes of learning. Teachers also believe that the method of accumulating authentic experience develops children's critical thinking and encourages to apply the acquired knowledge in practice, i.e. in life and in 
society. The research on the development of critical thinking (Indrašienè, Matonytė, Penkauskienè and Suboč, 2010) revealed that students have little opportunity to develop and substantiate critical thoughts, reflect on the progress of their thinking and activities; therefore, the application of the method of accumulating authentic experience in education solves this issue.

Informants claimed that learning motivation, using the method of accumulating authentic experience in children's education, manifests itself in encouraging students to understand their potential, experience success, get to know themselves better, and understand their role in the educational process. The application of the following method allows hard learners to enjoy success and good learners to have excuses to compete. Students deepen their knowledge in an area that interests them, have the opportunity to learn what they want. Moreover, content of lessons is aligned with students, and this helps them stay motivated to learn. The authentic experience method provides children with an opportunity to be autonomous, active, independent and responsible for their learning. Students can share their knowledge, they are encouraged to work in a team, which motivates weaker students to engage in activities, and rejoice in the success of the team. This means that hard learners experience the joy of learning and feel great in the classroom.

Teachers, who participated in the qualitative research, noticed that the application of the method of accumulating authentic experience in education activates the "inclusion" of the learning process - active learning opportunities are provided, interdisciplinary integration takes place, and the use of information communication technologies is wide. The following method makes it possible to link student's learning with one's own experience, and students offer their own topics. Each student learns to present the collected information to everybody in the classroom.

The method of accumulating authentic experience helps to develop critical thinking: it creates learning conditions that provide an opportunity to organize, interpret, explain, evaluate, explore, analyse information. By applying the following method, students collect information by using a variety of methods, which reveals students' learning potential, encourages students to think critically. With the help of the method, students are encouraged to search for the necessary information in various sources, children learn/are taught to select proper and improper information for the project or lesson. Accordingly, the following develops students' abilities to select appropriate information, process and apply it.

Qualitative research revealed that the method of accumulating authentic experience promotes the application of the acquired knowledge in life - not only in the classroom, but also outside of it. Children can see the connection between what they learn in an educational institution and how this knowledge is used in 
society, outside the educational institution. By applying the following method, students prepare projects that are related to life, students' living environment there is a real connection between the learning materials and practice, it makes sense for the student to learn. Moreover, the method provides an opportunity for children to socialize: get acquainted with nature, natural phenomena through experience.

Qualitative research sought to determine the opinion of informants about what types of media do primary school teachers use to promote authentic learning? The obtained data are presented in Table 2.

Table 2 Types of Media Used to Promote Children's Authentic Learning

\begin{tabular}{|l|l|l|l|}
\hline \multicolumn{1}{|c|}{ Category } & \multicolumn{1}{|c|}{ Subcategory } & \multicolumn{1}{|c|}{ Statements } & \multicolumn{1}{|c|}{$\begin{array}{c}\text { Number of } \\
\text { responses }\end{array}$} \\
\hline $\begin{array}{l}\text { Types of media } \\
\text { used to promote } \\
\text { children's } \\
\text { authentic } \\
\text { learning }\end{array}$ & Print media & $\begin{array}{l}\text { Books, magazines for children, } \\
\text { newspapers, encyclopaedias }\end{array}$ & 15 \\
\cline { 2 - 4 } & $\begin{array}{l}\text { Audio-visual } \\
\text { media }\end{array}$ & Television & 15 \\
\cline { 2 - 5 } & Visual & Photography & 4 \\
\cline { 2 - 5 } & $\begin{array}{l}\text { Acoustic/audio } \\
\text { media }\end{array}$ & Radio, phonography & 6 \\
\cline { 2 - 5 } & $\begin{array}{l}\text { Interactive } \\
\text { media }\end{array}$ & $\begin{array}{l}\text { Mobile phones (various applications), } \\
\text { tablets/computers (databases, search } \\
\text { engines, applications, games, movies, } \\
\text { programs, TV shows, etc.) }\end{array}$ & 15 \\
\hline
\end{tabular}

The research showed that in order to promote children's authentic learning, primary school teachers use both traditional types of media (print, audio-visual, audio) and interactive types of media (mobile phones (various applications), tablets/computers (databases, search engines, applications, games, movies, programs, TV shows, etc.). Photography, radio, phonography are used less often.

The opinion of informants about why is the use of media in children's authentic learning important? was clarified and provided in Table 3.

The research revealed that the importance of media in children's authentic learning is related to the development of media literacy and the promotion of cooperation with each other. According to the UNESCO definition, media and information literacy is a set of competencies that covers traditional and new media, as well as abilities related to them - from technical skills to visual and media literacy. Media literacy is closely linked to social inclusion, lifelong learning, creative problem-solving, activity and collaboration - cornerstones of modern society. 
SOCIETY. INTEGRATION. EDUCATION

Proceedings of the International Scientific Conference. Volume II, May $28^{\text {th }}-29^{\text {th }}$, 2021. 96-112

Table 3 The Importance of Media in Children's Authentic Learning

\begin{tabular}{|c|c|c|c|}
\hline Category & Subcategory & Statements & $\begin{array}{c}\text { Number of } \\
\text { responses }\end{array}$ \\
\hline \multirow[t]{2}{*}{$\begin{array}{l}\text { The } \\
\text { importance of } \\
\text { media } \\
\text { application in } \\
\text { children's } \\
\text { authentic } \\
\text { learning }\end{array}$} & $\begin{array}{l}\text { Development } \\
\text { of media } \\
\text { literacy }\end{array}$ & 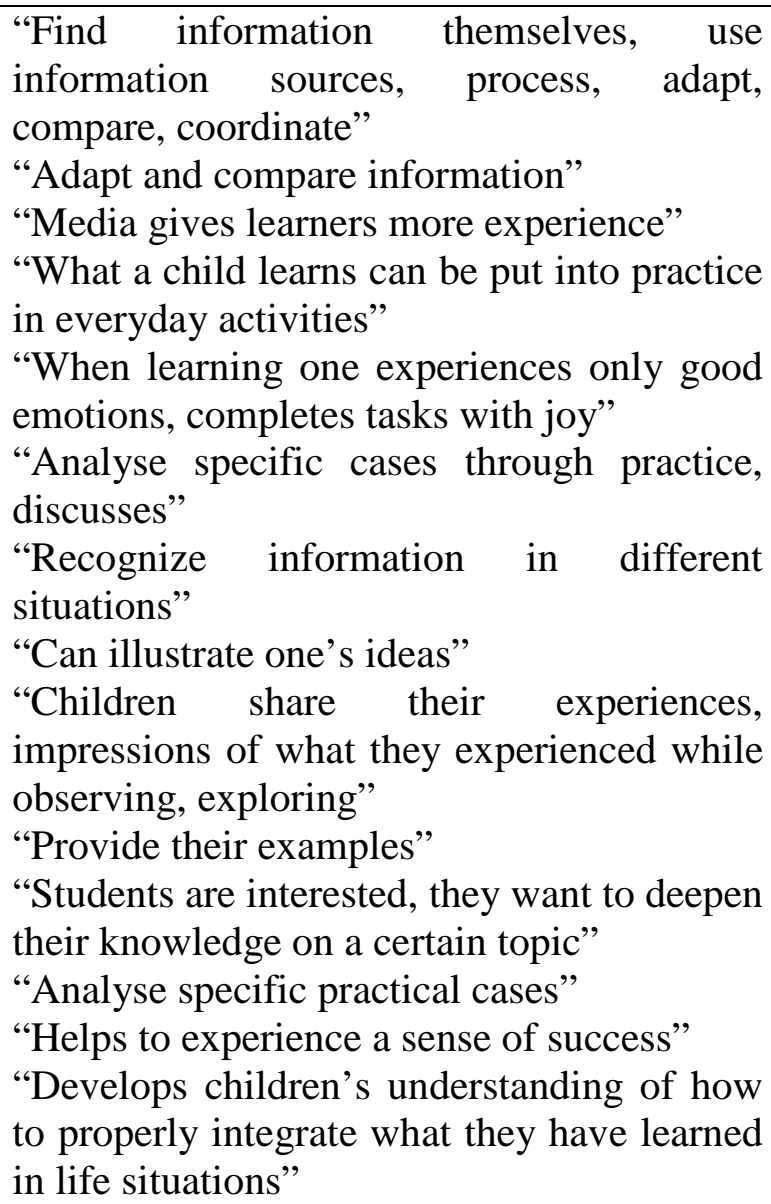 & 12 \\
\hline & $\begin{array}{l}\text { Promotion of } \\
\text { students' } \\
\text { cooperation }\end{array}$ & $\begin{array}{l}\text { "Students collaborate with classmates, } \\
\text { parents, teachers" } \\
\text { "Students teach each other" } \\
\text { "Collaborate with each other" } \\
\text { "Can share their success and knowledge with } \\
\text { others" } \\
\text { "Students teach each other, correct each } \\
\text { other's works" }\end{array}$ & 14 \\
\hline
\end{tabular}

Informants noted that the application of media in authentic learning is one of the ways of developing children's media literacy, because they find information themselves, use information sources, process, adapt, compare, coordinate, analyse specific practical cases, discuss. Media gives the learners more experience - what the child learns can be applied in practice in everyday activities. It is also important that while learning, the child experiences only good emotions, performs 
tasks with joy, and feels a sense of success. With the help of media, students recognize information in different situations, can illustrate their ideas, and provide their own examples. Through media, children share their experiences, impressions of what they have encountered while observing, exploring. Students are interested, which means they want to deepen their knowledge on a certain topic.

Primary school teachers, who participated in the research, noted that the importance of media in authentic learning is also determined by the promotion of cooperation - with classmates, parents, educators. Students teach each other, correct each other's works. Moreover, then can share their success and knowledge with others.

Qualitative research helped to find out the opinion of primary school teachers about what advantages and disadvantages do you see in the development of authentic learning experience through media? Data from questionnaires are presented in Table 4.

Table 4 Advantages and Disadvantages of Using Media in Developing Children's Authentic Learning Experience

\begin{tabular}{|c|c|c|c|}
\hline Category & Subcategory & Statements & $\begin{array}{c}\text { Number of } \\
\text { responses }\end{array}$ \\
\hline \multirow[b]{3}{*}{$\begin{array}{l}\text { Advantages } \\
\text { and } \\
\text { disadvantage } \\
\text { s of using } \\
\text { media in } \\
\text { developing } \\
\text { children's } \\
\text { authentic } \\
\text { learning } \\
\text { experience }\end{array}$} & $\begin{array}{l}\text { ADVANTA } \\
\text { GES }\end{array}$ & & 15 \\
\hline & $\begin{array}{l}\text { Improvemen } \\
\text { t of the study } \\
\text { process } \\
\text { quality }\end{array}$ & $\begin{array}{l}\text { "Teacher-convenient method" } \\
\text { "An attractive educational method for the } \\
\text { modern student" } \\
\text { "A great way to lean anywhere and anytime" } \\
\text { "Wide range of application of the method" } \\
\text { "Develops ICT skills" } \\
\text { "Promotes motivation to learn" } \\
\text { "Children can apply their knowledge and } \\
\text { skills" }\end{array}$ & 13 \\
\hline & $\begin{array}{l}\text { Developmen } \\
\text { t of students' } \\
\text { communicat } \\
\text { ion skills } \\
\text { and critical } \\
\text { thinking }\end{array}$ & $\begin{array}{l}\text { "Media allows to illustrate one's ideas" } \\
\text { "What is learned can be applied in other } \\
\text { activities, in life" } \\
\text { "Easily accessible information" } \\
\text { "Develops critical thinking" } \\
\text { "Children are encouraged to communicate and } \\
\text { collaborate, develop, self-assess their abilities" } \\
\text { "Develops communication skills and critical } \\
\text { thinking" } \\
\text { "Promotes creativity and collaboration" } \\
\text { "Students understand the importance of their } \\
\text { authentic experience and the media makes it } \\
\text { easier to remember that" }\end{array}$ & 12 \\
\hline
\end{tabular}




\begin{tabular}{|c|c|c|}
\hline $\begin{array}{l}\text { DISADVA } \\
\text { NTAGES }\end{array}$ & & 15 \\
\hline $\begin{array}{l}\text { Damage to } \\
\text { the mental } \\
\text { and physical } \\
\text { health of the } \\
\text { child }\end{array}$ & $\begin{array}{l}\text { "Long time spend with media reduces } \\
\text { children's creativity" } \\
\text { "May be harmful to health if a lot of time is } \\
\text { spend with media" } \\
\text { "Reduces students' physical activity" } \\
\text { "Application of media even more attracts } \\
\text { children to technologies that are already a } \\
\text { major problem" }\end{array}$ & 14 \\
\hline $\begin{array}{l}\text { Uncertainty } \\
\text { in the quality } \\
\text { of education }\end{array}$ & $\begin{array}{l}\text { "Lack of systematic approach, methodology" } \\
\text { "Takes more lesson time than usual" } \\
\text { "There is no direct contact with the teacher and } \\
\text { not everyone can study independently" } \\
\text { "Not all schools are equipped with the } \\
\text { necessary media, poor internet connection" } \\
\text { "Not recommended for students with lower } \\
\text { abilities (or teachers need to adapt tasks)" } \\
\text { "Media management is time consuming, it is } \\
\text { difficult to reconcile with mandatory teaching } \\
\text { standards" } \\
\text { "Some students find it difficult to select } \\
\text { necessary information, because there is too } \\
\text { much of it" } \\
\text { "There are students who cannot use different } \\
\text { media" } \\
\text { "Direct contact with the student decreases" } \\
\text { "It is difficult for a child not to get lost in the } \\
\text { abundance of information" } \\
\text { "A child sometimes needs parental help/care } \\
\text { when using media" }\end{array}$ & 15 \\
\hline
\end{tabular}

Primary school teachers noted that advantages of using media in the development of children's authentic learning experience are related to the improvement of the quality of the educational process: a convenient method for the teacher and an attractive educational method for the modern student, when it is possible to learn anywhere and anytime. With the help of media, children develop ICT skills and can also apply the existing knowledge and skills, which stimulates students' motivation to learn. The application of media in the development of children's authentic learning experiences is also relevant for the development of communication skills and critical thinking, as information is easily accessible and what students learn can be applied in other activities, in life. Through media, children are encouraged to communicate and collaborate, create, self-assess their abilities, illustrate their ideas. Media develops communication 
skills and critical thinking, promotes creativity and collaboration. In developing an authentic learning experience, students understand the importance of their authentic experience, and the media makes it easier to memorize it.

However, teachers stated that the application of media in the educational process also has disadvantages, which are actualized by the damage caused by media to the child's mental and physical health: long hours spend with media reduces children's creativity, reduces students' physical activity. Educators emphasized that the application of media attracts children to technology even more, which is already a big problem. Informants noted the uncertainty of the quality of education as a disadvantage in the application of media in the development of children's authentic learning experience, because there is a lack of a systematic approach and methodology on the application of media in the educational process. The use of media takes more lesson time compared to conventional work, it is difficult to reconcile with mandatory teaching standards. Moreover, the student's direct contact with the teacher decreases, and not everyone can study independently. Some students find it difficult to select the information they need, as there is too much of it, and there are students, who are unable to use a variety of media. Educators also stated that not all schools are equipped with the necessary media and have poor internet connection.

\section{Conclusions}

1. Theoretical analysis revealed that the importance of student's authentic experience is evident through experiential learning/teaching. It is an active student-centred learning strategy that is based on the ideas of constructivist theory, which draw attention to the process of learners actively constructing and making their own knowledge. The authentic learning of students takes place when educators foster the growth and improvement of each child, enable children to act freely, explore, discuss and construct concepts and relationships that encompass real-world problems through the use of media. Researchers that emphasize the advantages of experiential learning note that modern teaching/learning should comply with the following principles: it should be realistic, relevant, attractive, motivating; it should be clear, precise, i.e. aimed at a specific aim and addressee; it should give students autonomy; it should be adapted for students with different teaching/learning needs and styles; it should create opportunities to take on different roles and responsibilities; it should broaden the horizon and encourage to seek more. Authentic learning is defined as learning that is seamlessly integrated or implanted into meaningful, "real-life" situations, new knowledge is created here and now, the teaching/learning process becomes more authentic. 
2. The analysis of research's results revealed that the method of accumulating authentic experience in children's education makes a learning process more positive, inclusive, and develops children's critical thinking and motivates to apply knowledge in practice. According to educators, the meaning of children's authentic experience is especially evident in interdisciplinary integrational activities through the use of the media. In their opinion, in order to give meaning to the authentic experience pupils have, the media used in the learning process gives children more experience, while learning they experience only positive emotions, can illustrate their ideas, present their experience. In the interviews, educators identified not only advantages but also disadvantages of developing a child's authentic learning experience through the media: the child's own systematic approach to the quality of education, choice of methodologies and their application in the educational process through various media, as well as the ability of pupils to learn independently. The findings of this study suggest that the authentic experience of pupils can be made meaningful while in the educational process, when the foundations of learning that remain important throughout life are laid. The research is relevant and requires continuity in order to reveal the importance of the student's authentic experience both in the activities initiated by the educators and in the children's contribution to the organization of the learning process itself.

\section{References}

Anderson, D., Hartwig, E. A. (2016). Authentic Assessment: A Critical Tool for Early Childhood Educators. New York Early Childhood Professional Development Institute. Retrieved from: https://earlychildhoodny.org/blog/authentic-assessment-a-critical-toolfor-early-childhood-educators/

Bitinas, B. (2013). Rinktiniai edukologinai raštai. 2 T. Vilnius: Edukologija.

Braslauskienė, R., Norvilienè, A., Šmitienè, G., Vismantienė, R. (2018). Patirtinis ugdymas(is) vaikystèje: šiuolaikinès medijos ir informaciniu komunikaciniu technologiju galimybès. Klaipeda: Klaipèdos universiteto leidykla.

Breunig, M. (2005). Turning Experiential Education and Critical Pedagogy Theory into Praxis. Journal of Experiential Education, Vol. 28, No. 2, 106-122.

Buckingham, D. (2000). The Making of Citizens: Young People, News and Politics. London: Routledge.

Carlson, A. (2002). Authentic learning: What does it really mean? Western Washington University. Retrieved from: https://www.sciencedirect.com/science/article/pii/S1877 042814046308/pdf?md5=bfe9b00e1b37670ce9cc556f466eb528\&pid=1-s2.0S1877042814046308-main.pdf

European Agency for Special Needs and Inclusive Education. (2014). Inclusive Education in Europe: Putting Theory Into practice. International Conference. First Results. Retrieved from: https://www.european-agency.org/sites/default/files/International\%20Conference\%20First\%20resultst_0.pdf 
French, G. (2007). The Framework for Early Learning: a Background Paper:Children's Early Learning and Development Executive Summary. Technological University Dublin. Retrieved from: https://arrow.tudublin.ie/cgi/viewcontent.cgi?article=1011\&context= aaschsslrep

Gaučaitè, R., Kazlauskienė, A., Masiliauskienè, E. ir kt. (2012). Mokymosi mokytis strategijos. Autentiškas mokymasis: būdai, aplinkos, šaltiniai, metodai. Šiauliai: Šiaulių universiteto leidykla.

Global Challenge Insight Report. (2016). The Future of Jobs Employment, Skills and Workforce Strategy for the Fourth Industrial Revolution. World Econimic Forum. Retrieved from: http://www3.weforum.org/docs/WEF_Future_of_Jobs.pdf

Grizzle, A. (2011). Media \& Information Literacy: The UNESCO Perspective. In School 2.0. A global perspective. The Journal of Media Literacy. Vol. 57, p. 1-2.

Indrašienè, V., Matonytè, A., Penkauskienè, D. ir Suboč, V. (2010). Kritinio mastymo ugdymo principu integravimas $i$ Lietuvos bendrojo ugdymo sistema. Šiuolaikinių didaktikų centras.

Iucua, R. B., Marina, E. (2014). Authentic Learning in Adult Education. Social and Behavioral Sciences. Vol. 142, p. 410 - 415. Retrieved from: https://www.sciencedirect.com/science/ article/pii/S1877042814046308/pdf?md5=bfe9b00e1b37670ce9cc556f466eb528\&pid= 1-s2.0-S1877042814046308-main.pdf

Jančiauskaitè, R. (2016). Mediju informacinio raštingumo teikiamos galimybès geresniam užsienio kalbu mokymuisi. Mokiniu mokymosi gerinimas: i pagalba mokytojui. Metodinè priemonè (red. J. Navickaitè). Vilnius: Ugdymo plètotès centras.

Jonassen, D., Howland, J., Marra, R.M., Crismond, D. (2008). Meaningful learning with technology (3rd ed.). Upper Saddle River: Pearson Education, Inc. Retrieved from: https://www.pearson.com/us/higher-education/product/Jonassen-Meaningful-Learningwith-Technology-3rd-Edition/9780132393959.html

Mims, C. (2003). Authentic learning: A practical introduction and guide for implementation. Meridian: A Middle School Computer Technologies Journal, 6 (1). Retrieved from: https://www.researchgate.net/publication/228395999_Authentic_Learning_A_practical_ introduction_and_guide_for_implementation

Monkevičienè, O., Sakadolskis, E. A., Bruzgelevičienė, R., Jakavonytè-Staškuvienè, D., Salienè, V., Toleikytè, N., Zaleskienè, I., (2014). Ugdymo paradigmu iššūkiai didaktikai: kolektyvine monografija. Vilnius: Lietuvos edukologijos universiteto leidykla.

Moon, J. A. (2005). A Handbook of Reflective and Experiential Learning. Theory and Practice. Taylor \& Francis e-Library. Retrieved from: http://perpustakaandeajulia.weebly.com/ uploads/1/8/2/6/18261275/a_handbook_of_reflective_and_experiential_learning_theory_and_practice.pdf

Petty, G. (2006). Šiuolaikinis mokymas. Praktinis vadovas. Vilnius: Tyto alba.

Schwab, K. (2016). The Fourth Industrial Revolution: what it means, how to respond. World Economic Forum. Retrieved from: https://www.weforum.org/agenda/2016/01/thefourth-industrial-revolution-what-it-means-and-how-to-respond/

Šupšáková, B. (2016). Media Education of Children and Youth as a Path to Media Literacy. Communication Today, Vol. 7, No. 1. Retrieved from: https://www.communicationto day.sk/download/12016/SUPSAKOVA-\%25E2\%2580\% 2593-CT-1-2016.pdf 
Vaščenkienė, O. (2012). Šiuolaikinio mokymosi apibrėžimas. Kompetenciju ugdymas:metodine knyga mokytojui. Retrieved from: https://sodas.ugdome.lt/metodiniai-dokumentai/ perziura/3402

Vosniadou, S. (2011). How children learn. International Academy of Education. International Bureau of Education. Retrieved from: http://www.ibe.unesco.org/sites/default/files/ resources/edu-practices_07_eng.pdf

Voukelatou, G., (2019). The Contribution of Experiential Learning to the Development of Cognitive and Social Skills in Secondary Education: A Case Study. Education Sciences. No. 9(2), 127.

Warren, J., Hof, K., McGriff, D., Morris, L. (2012). Five Experiential Learning Activities in Addictions Education. Journal of Creativity in Mental Health. No. 7(3), 272-288.

Žydžiūnaitė, V., Sabaliauskas, S. (2017). Kokybiniai tyrimai: principai ir metodai. Vilnius: Vaga. 